\title{
How We Narrate Dance
}

Jochen Roller, Friederike Lampert

Dance history happens skin to skin. ${ }^{1}$

(Stephen Petronio)

\section{Inside Dance History}

Das Forschungsprojekt Inside Dance History an der ZHdK untersucht tanzgeschichtliches und tanztechnisches Wissen als Embodied Practice von Tänzer*innen und Choreograf*innen. Das Projekt ist der Versuch, ein Narrativ zu generieren, das die Lehr- und Lernrealität von zeitgenössischen Tanzausbildungen an Kunsthochschulen wiedergibt. Inside Dance History erforscht die Tanzgeschichte deshalb aus der Perspektive der Tänzer*innen und Choreograf*innen. Der Forschungsansatz unterscheidet sich insofern von der Tanzwissenschaft, als dass der Tanz nicht als flüchtiges Phänomen verstanden wird, das es durch verbale Beschreibung und schriftliche Analyse einzufangen gilt, sondern als Embodied Practice, bei der die Aus- und Aufführung von Tanz auch immer die Performance von Körper-Wissen ist. Dabei konzentriert sich die Forschung auf audio-visuelle Formen der digitalen Archivierung als Medium der Wissensweitergabe.

Der vorliegende Beitrag fragt essayistisch nach der Rolle, die Serendipität in der Entstehung von Tanzgeschichte und Tanztechnik spielt. Es handelt sich um situative Zufälle aus dem Tanzstudio, die bedeutsame Merkmale von Tanzformen hervorgebracht haben und oftmals unter einem Schleier verborgen bleiben. In der Form der Anekdote lassen sich solche Situationen materialisieren und weitergeben - das Inside(r)-Wissen wird auf diese Weise zu einem Archiv, das einen direkten Zugang zu tänzerischer Wissenskultur erschließt. Der vorliegende Abdruck ist das Transkript einer Online Lecture im Powerpoint-Format.

1 Stephen Petronio in: Maia Wechsler (2018): If the Dancer Dances, DVD, Produktion: Lise Friedman, Maia Wechsler. 
Friederike Lampert/ Jochen Roller:

How We Narrate Dance
Graham technique is based on the opposition between contraction and release, a concept based on the breathing cycle which has become a ,trademark' of modern dance forms. Its other dominant principle is the ,Spiraling' of the torso around the axis of the spine.
If you google

Graham technique, this comes up first.
Contraction and Release is a concept based on the breathing

cycle that we find in many modern and contemporary dance techniques.
What about the other dominant principle of Graham technique?

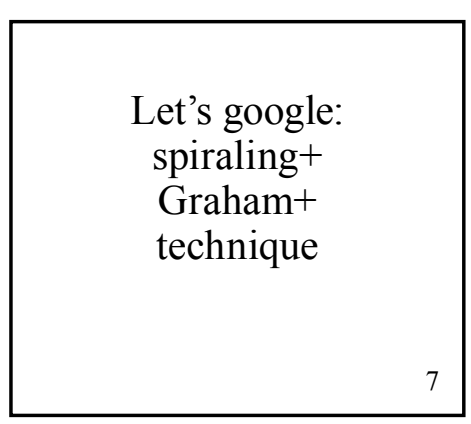

The Spiraling of the torso around the axis of the spine?

Additionally, since Graham technique emphasizes spirals in the body, observing the form and energy of spirals in nature - in plants, for instance - may help you understand how the pelvis and the spine work together in twisting and curving the torso. 


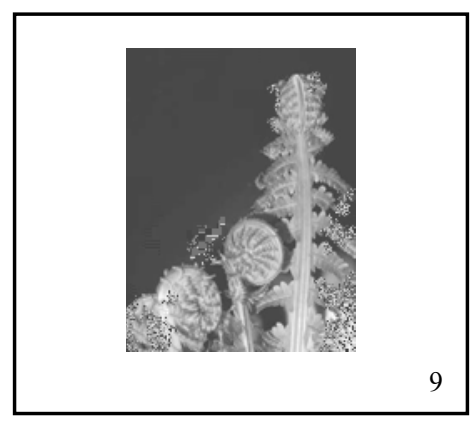

„Alignment begins in the lower torso at the base of the spine. The

lift of tense buttocks, hips and stomach stretches upwards through the core of the body to the base of the throat. A vertical line between the base of the spine and the base of the throat centers the erect torso."

(The Martha Graham Dance Legacy Project)

„I am certain that movement never lies. There is only one law of posture I have been able to discover - the perpendicular line connecting heaven and earth." (Martha Graham)

So spiraling is about connecting heaven and earth.

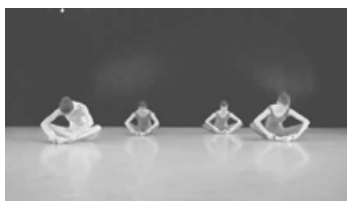

Over. Stretch. Stretch. Curve. Pull. Together. And one. Curve. And Pull. Together. And one. 

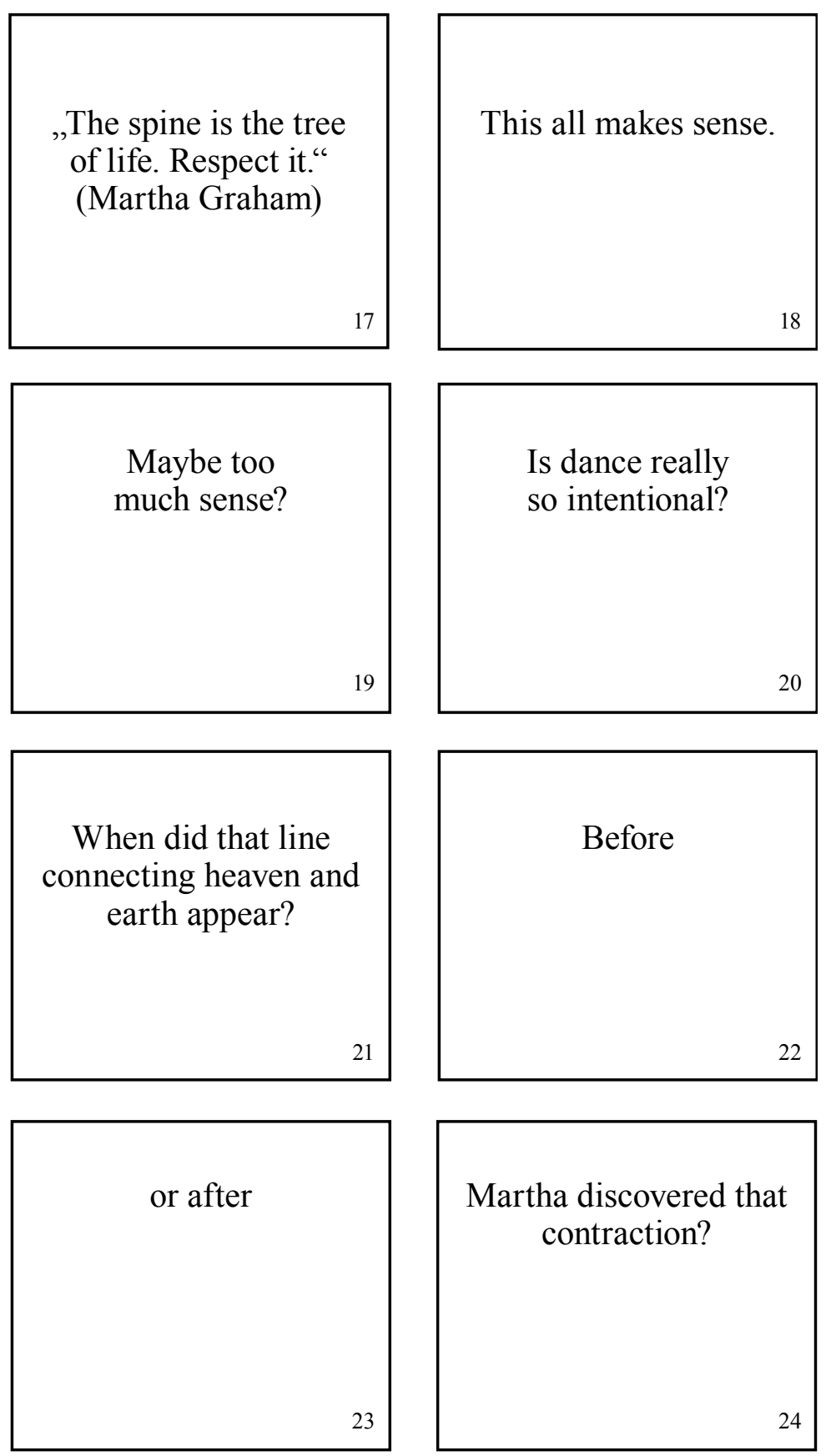


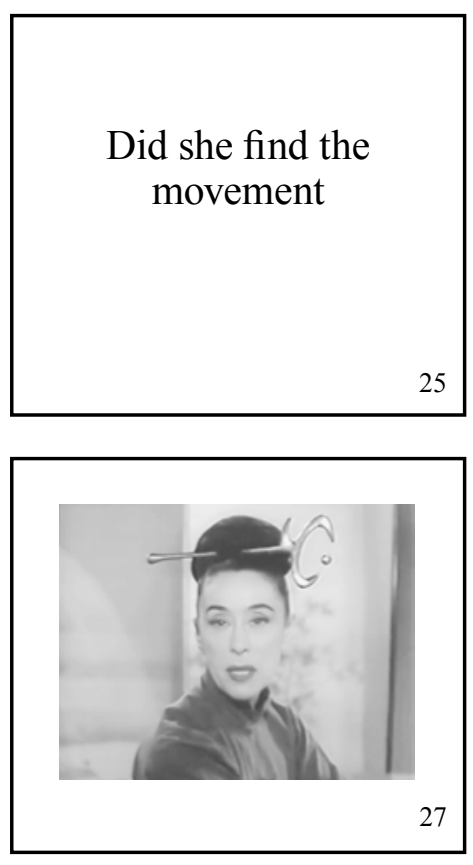

or the meaning of the movement?

„This is not competition. There

is no competition. You are in competition with one person only and that is the individual you know you can become. And that is a thing that makes a dancer's life the life of a realist and gives it some of its hazards and some of its wonder. It is a creative process." (Martha Graham)

A dancer's life has its hazard and its wonder.

It's a creative process.

Are we looking for the hazard or the wonder? 

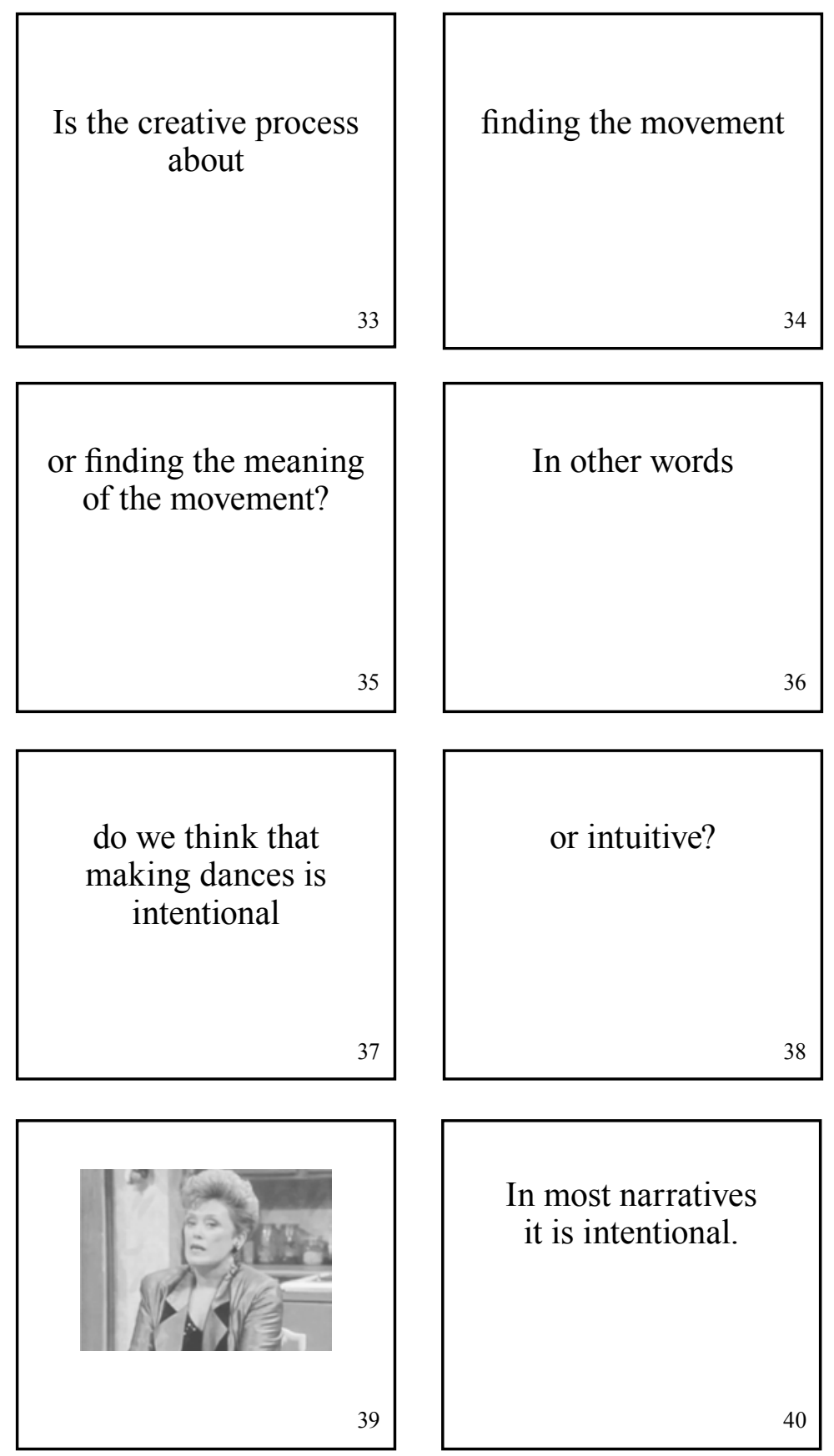


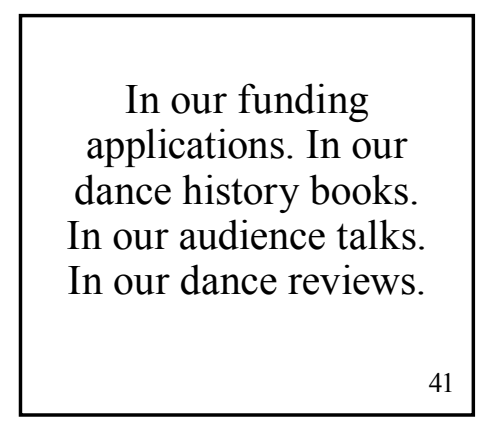

But what if the hazard of the creative process was its wonder?
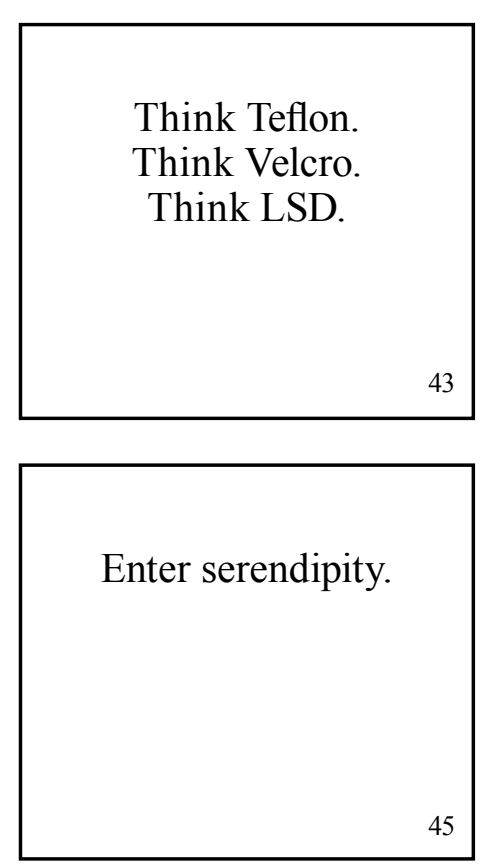

A principle based on the Persian tale ,The 3 Princes of Serendip“ in which the princes make discoveries of things they are not looking for.

Which does not mean they are not searching.

They just don't know what they are searching for. 
In our funding applications. In our dance history books. In our audience talks. In our dance reviews.

„How many leaps did Nijinsky take before he made the one that startled the world? He took thousands and thousands and thousands. And it's that legend that gives us all energy and strength to go back into the studio to work again among the many that we may be once be reborn as the one."

(Martha Graham)

then why is the written dance history such a straight story of intentions?

Enter the anecdote.

If Nijinsky took all these leaps without knowing what he was looking for
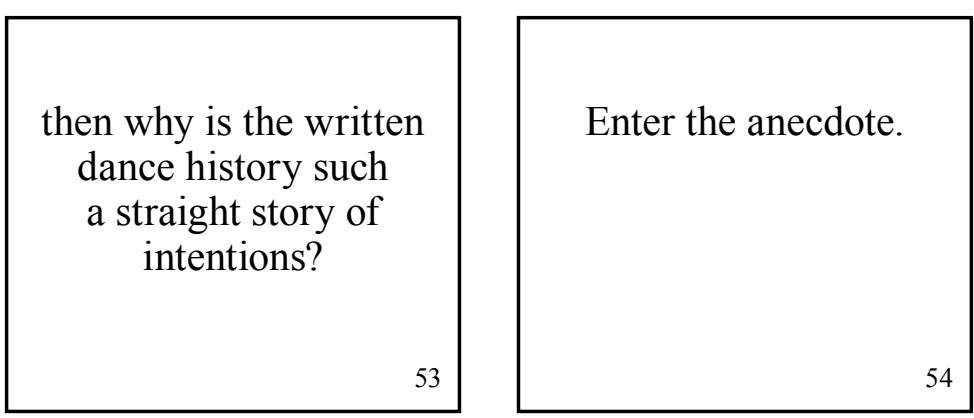

Our tool of an oral dance history.
The pragmatic revealer of situational hazards that later turned into intentional narratives. 


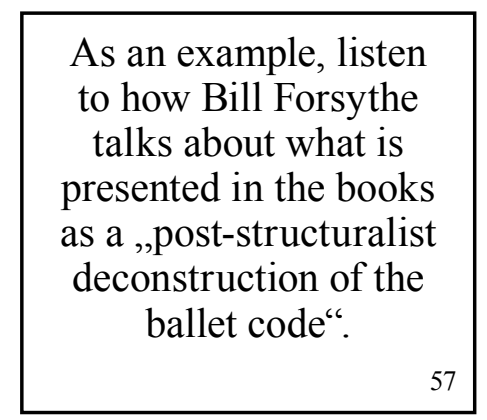

„We were sort of the people who basically took ballet off balance. It was a ,why not mentality“. I was talking to Merce Cunningham once and he did this really goofy thing. Merce said to me: ,I said to myself: Why not?' That was pretty much our attitude. Almost like an algorithm. If this - then what? We didn't know. We try things and then deal with the results." (William Forsythe)

Dealing with the results of creative processes can naturally lead to defining this process

But from a dancer's view, the written narratives of our dances are too intentional.

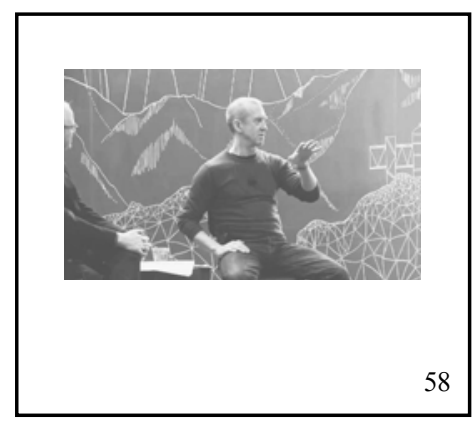

We try things and then we deal with the results.

as a ,post-structuralist deconstruction of the ballet code“".

There are so many stories out there of dances that took on a specific form because they were invented in spaces that were too small. 
There are so many stories out there of dances that took on a specific form because they were invented by dancers that were too small.

You can call these dances whatever you like.

Which might not be as intentional as you make them.
There are so many stories out there of dances that took on a specific form because they were invented by dancers whose budget was too small.

But you also need to acknowledge the dynamics of the creative process.

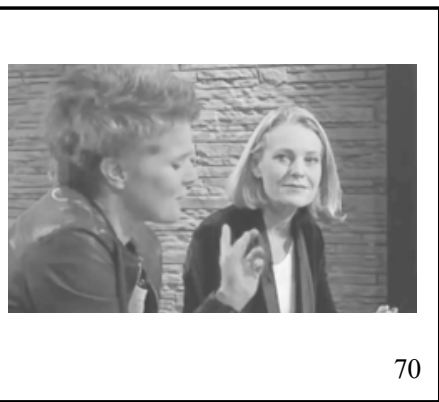

„An important key word is narration. How we narrate our life retrospectively. When we narrate our own life we tend to eliminate chance. In retrospective, everything makes sense. This is my path of life and everything looks like it evolved really organically. Of course we also gloss over some things so that something that wasn't actually good for you was in the end good for your life. This retrospective narration eliminates all chance." (Svenja Flaspöhler)
Serendipity has an antagonist called bahramdipity. 
Bahramdipity is the suppression of a serendipitous discovery by a powerful individual

that favors a narrative based on intention over a narrative based on intuition.
Creative processes are full of hazards and wonders.

Think Teflon.

Think Velcro. Think LSD.

„LSD has multiply effects. There is the sensory effects - synesthesia, hallucination - there is the euphoria, but LSD and several other drugs including marijuana also stimulate brain centers that attach meaning to external stimulae." (Perry Wilson)

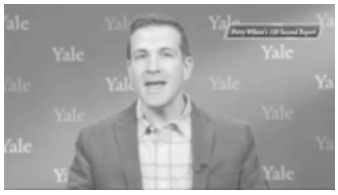

Let's keep stimulating our brain centers by attaching meaning to external stimulae.

But also, let's find a place for serendipity in our dance history and start to tell the story of dance from a dancer's view. 
Sources:

Glushanok, Peter (1957): A Dancer's World, TV-Movie,

Pittsburg, Pennsylvania: WQED.

Suggs, Jeanne (1997): The Martha

Graham Dance Legacy Project, New York: Suggs Media Productions [online] https://www.youtube.com/ watch?v=vitRYWTQuys [30.04.2020]

SRF Kultur (2019): Das Unerwartete erwarten - vom klugen Umgang mit dem Zufall, Sternstunde Philosophie with Svenja Flasspöhler, Miriam Meckel and Barbara Bleisch [online] https://www.srf.ch/play/tv/sternstundephilosophie/video/das-unerwarteteerwarten---vom-klugen-umgang-mitdem-zufall?id=68eccc $5-4127-4 \mathrm{c} 19$ b691-0450c9d5493a [30.04.2020]
Murray, Timothy (2014): A conversation with William Forsythe, Cornell

University [online] https://www. cornell.edu/video/conversation-withwilliam-forsythe-and-timothy-murray [30.04.2020]

NBC Series (1985-1992): Golden Girls, created by Susan Harris

Wilson, Perry (2017): Study yields surprise on LSD's mechanism of action [online] https://www.youtube.com/ watch? $\mathrm{v}=\mathrm{h} 7 \mathrm{XBJ}$ JoxWspE [30.04.2020] 